\title{
Marta Sobieszewska
}

Uniwersytet Marii Curie-Skłodowskiej

marta.sobieszewska@gmail.com

\section{Juryslingwistyka: między językiem a prawem}

\author{
Jurislinguistics: Between Language and Law
}

\section{STRESZCZENIE}

W artykule zostały omówione szczególne relacje występujące między językiem a prawem oraz związana z nimi nowa dyscyplina badawcza o nazwie juryslingwistyka. Z uwagi na jej szczególną rolę w kontekście prawno-ekonomicznym (jak w przypadku Unii Europejskiej) moim celem było przedstawienie genezy i ewolucji omawianych zjawisk, a także ukazanie możliwości jej zastosowania w perspektywie thumaczenia tekstów prawa na języki obce.

Słowa kluczowe: język; prawo; język prawa; juryslingwistyka

Le droit est affaire de mots.

J.-C. Gémar

\section{HYBRYDOWA DYSCYPLINA}

Termin ,juryslingwistyka” został użyty po raz pierwszy w latach 70. XX wieku w Kanadzie. Przyjmuje się, że to właśnie Kanada, z uwagi na współistnienie dwóch kultur prawnych (bijuridisme) i dwóch języków (bilinguisme), odegrała pionierską rolę $\mathrm{w}$ rozwoju juryslingwistyki. Do rozpowszechnienia tej nazwy przyczynił się prof. J.-C. Gémar, publikując wyniki swoich badań dotyczących thumaczenia tekstów prawa ${ }^{1}$. Badacz tłumaczył użycie neologizmu jego zdolnością zastosowania zarówno do badań językoznawczych, jak i do badań traduktologicznych języka prawa. $\mathrm{W}$ ten sposób Gémar położył fundamenty pod nową dyscyplinę badawczą usytuowaną na skrzyżowaniu dwóch dyscyplin matek²: lin-

${ }^{1}$ J.-C. Gémar, Langage du droit et traduction. Essai de jurilinguistique. The Language of the Law and Translation. Essays on Jurilinguistics, Québec - Montréal 1982.

${ }^{2}$ Idem, Traduire ou l'art d'interpréter. Langue, droit et société : éléments de jurilinguistique, 2 Vol., Québec 1995. 
gwistyki i prawa. Scalenie autonomicznych dziedzin, wywodzących się z różnych obszarów naukowych, doprowadziło do powstania w ich obrębie dyscypliny, która wykazuje specyficzne właściwości decydujące o „wyższości” nowej, hybrydowej formy. W świecie nauki oznacza to nową perspektywę badawczą oraz możliwość wzajemnego korzystania z osiągniętych ustaleń. Jest to o tyle istotne, że dotychczasowe badania nad językiem prawa, prowadzone w ramach teorii prawa i językoznawstwa, były najczęściej od siebie niezależne.

W tym samym czasie myśl, że prawo może być badane jako system znaków językowych stopniowo torowała drogę juryslingwistyce w Europie. Niekwestionowany wkład w jej rozwój wniósł Ch. Perelman, prezentując założenia teorii argumentacji i rozumowania prawniczego. Na szczególną uwagę zasługują również pierwsze prace językoznawców i prawników badających język prawa, tj. J.-L. Souriouxa i P. Lerata: Le langage du droit, następnie artykuł Le discours juridique : analyses et méthodes opublikowany w „Langages”, oraz specjalny numer czasopisma „Meta”, poświęcony przekładowi prawniczemu.

Początkowo francuscy specjaliści nie chcieli używać zapożyczonego z Kanady terminu ,juryslingwistyka” i częściej posługiwali się określeniem „lingwistyka prawa"4 (linguistique juridique). Wynikało to przede wszystkim z odmiennego kontekstu, w którym istnieje jeden język narodowy i jeden system prawny. Badania francuskich językoznawców nie były szczególnie skoncentrowane na thumaczeniu prawa, jak to miało miejsce w Kanadzie, lecz na analizach typu opisowego, głównie w zakresie leksykologii, retoryki i dyskursu. Dlatego też, kiedy w 1990 roku została opublikowana pierwsza edycja słynnej pracy G. Cornu Linguistique juridique, jej autor zaproponował na określenie badań językoznawczo-prawniczych termin ,lingwistyka prawa”.

Warto zauważyć, że obie nazwy: ,juryslingwistyka” i „lingwistyka prawa”, mimo że konkurują ze sobą na gruncie języka francuskiego, dotyczą tej samej dyscypliny. Oczywiście różnią się między sobą pewnymi niuansami. Zdaniem Cornu pole badań oferowane przez lingwistykę prawa jest zdecydowanie szersze, ponieważ obejmuje nie tylko analizę językoznawczą języka prawa, ale także badanie praw języka. Natomiast według Gémara, mimo że juryslingwistyka polega na językoznawczym badaniu tekstów prawa we wszystkich jego formach, to jednak nie powinna być mylona z badaniem reguł czy też norm językowych.

Ostatecznie, mimo tych różnic, eksperci uznali oba terminy jako rodzaj wymiennych para-synonimów. Stało się tak prawdopodobnie wskutek publikacji

${ }^{3}$ „Meta” 1979, Vol. 24, n 1 , mars.

${ }^{4} \mathrm{Z}$ uwagi na niejednoznaczność thumaczenia na język polski francuskiego przymiotnika juridique ('prawny, prawniczy') oraz wciąż popularne w Polsce rozróżnienie języka prawnego i prawniczego (zob. B. Wróblewski, Język prawny i prawniczy, Kraków 1948), proponuję tłumaczyć francuski termin linguistique juridique jako „lingwistyka prawa”. Pozwoli to uniknąć niepotrzebnych nieporozumień. 
dzieła napisanego pod redakcją J.-C. Gémara i N. Kasirera pt. Jurilinguistique : entre langues et droits, które zawierało aktualne wyniki badań dotyczące tej dyscypliny. Synonimiczne podejście do obu terminów potwierdziła także z jednej strony grupa badawcza Groupe de Recherches en Jurilinguistique Appliquée (le GREJA) IniTerm z Uniwersytetu Lyon 3 (Wirualny Wydział Prawa), a z drugiej - specjalny numer czasopisma "Revue internationale de sémiotique juridique" (2008, Vol. 21, n ${ }^{\circ}$ ), symptomatycznie zatytułowany La linguistique juridique ou jurilinguistique : Hommage à Gerard Cornu.

Aktualnie podkreśla się często, że zarówno juryslingwistyka, jak i lingwistyka prawa reprezentują sektor badań interdyscyplinarnych par excellence, który od lat 90. skumulował ogromne bogactwo danych językowych i międzykulturowych niezbędnych do zrozumienia prawa. Dyscyplina ta, badając znaczenia i formy wyrazów używanych w prawie, stanowi ogromną pomoc w jego redagowaniu, rozumieniu, interpretacji (a więc i thumaczeniu) oraz wykonaniu. Istotną rolę odgrywają także zrodzone z niej późniejsze awatary, takie jak lingwistyka tekstu, analiza dyskursu i terminologii prawa. Ponadto warto zauważyć, że podział na języki specjalistyczne ${ }^{5}$ w rozumieniu praktycznych zastosowań języka w dziedzinach aktywności ludzkiej, rozciągnął się na studia językowe, tworząc nowe specjalności dla tłumaczy. W konsekwencji odmienność i specyfika języka prawa w porównaniu z innymi językami specjalistycznymi (np. medycyny, ekonomii itp.) oraz istotne znaczenie prawa sui generis, przyczyniły się do powstania odrębnej metody badawczej, jakiej nie wykształcił żaden inny język specjalistyczny.

Zważywszy na relatywnie młody wiek juryslingwistyki, należy podkreślić, że materialna część doktryny stopniowo się kształtuje, a jej savoir-faire upowszechnia się dzięki rozsianym po świecie juryslingwistom, działającym w ramach różnych instytucji międzynarodowych (np. UE, ONZ) i państwowych (np. ministerstwa) lub w prywatnych agencjach thumaczeniowych.

\section{JĘZYK PRAWA}

Tymczasem juryslingwistyka nie jest tak młoda, jak to się zwykle przyjmuje. Właściwie sięga ona do prehistorycznego prawa i jego zapisów, czyli do pierwszych prób redagowania kodeksów za pomocą pisma klinowego, czego monumentalnym przykładem jest kodeks Hammurabiego (ok. 1750 rok p.n.e.). Generalnie filozofów i prawników zajmowała nie tylko sprawiedliwość i wynikające z niej reguły prawa, ale także styl i forma, w jakiej były przedstawiane. Przykłady takiej postawy można mnożyć, począwszy od Cycerona do sir Williama Blackstone’a czy sędziego Lorda Denninga, autora słynnej rady: „Musi Pan używać

\footnotetext{
${ }^{5}$ P. Lerat, Les langues spécialisées, Paris 1995.
} 
słów prostych i jasnych, które pańscy słuchacze i czytelnicy będą mogli zrozumieć" . Problemem tym zajmował się również Monteskiusz, zalecając w De l'Esprit des lois, aby prawodawcy używali jasnych i prostych wyrażeń językowych. Dowodził on, że prawa nie powinny być zawiłe, ponieważ adresowane są do „ludzi miernego pojęcia”. Bentham ${ }^{7}$ także postulował dostosowanie kodeksów do możliwości pojmowania ich przez ludzi najmniej wykształconych. Jednak najbardziej radykalne stanowisko zajął Beccaria ${ }^{8}$, występując przeciwko wykładni dokonywanej przez sędziów. Uznał on, że wykładnia praw jest złem wynikającym z ich niejasności, a prawa stają się niejasne, kiedy pisane są językiem obcym ludowi. W związku z takimi postulatami nasuwa się wniosek, że społeczeństwa od dawna oczekują od ustawodawców jasnego i zrozumiałego prawa.

Każdy naród zgodnie ze swoją kulturą i obyczajami rozwinął własną tradycję redagowania tekstów prawnych. Każdy język posiada zabawne lub ironiczne świadectwo żargonu prawniczego, napisane piórem wielkiego pisarza (tj. Chaucera, Szekspira, Rabelais'go, Voltaire'a, Beaumarchais'go, Fredry i innych). Wynika to z faktu, że język prawa nie cieszy się dobrą opinią wśród ogółu. Nazywany we Francji językiem sędziego Don Guzmana Gąski ${ }^{9}$ (la langue de Brid'oison), irytuje archaicznym stylem, niezrozumiałą terminologią i ogólnym brakiem jasności. Można chyba powiedzieć, że jasność i zrozumiałość prawa są od wieków, niczym legendarny Graal, obiektem pożądania wielu ludzi.

\section{ZWIĄZKI JĘZYKA I PRAWA}

W przypadku juryslingwistyki fundamentalna refleksja nad związkami języka i prawa opiera się na założeniu różnorodności języków i mnogości praw. Prawo, jak to ujął metaforycznie Cornu, przemawia „tysiącem ust" ${ }^{10}$, stąd też dyskurs prawny ma charakter polifoniczny. Całokształt tego dyskursu jest istotnym zagadnieniem dotyczącym sformułowań prawnych oraz transpozycji językowej w środowisku wielojęzycznym i multijurysdycznym.

Istnieje wiele metod badania związków języka i prawa. W ontologicznej refleksji uzasadniona wydaje się myśl, że prawo jest przez język zdeterminowane. W tym ujęciu język posiada własną energię, która pozwala mu narzucić swą naturę prawu w taki sposób, że nawet daleki od chęci ujarzmienia języka prawnik

${ }^{6}$ Oryg. „Vous devez utiliser des mots simples et clairs que tous vos auditeurs et lecteurs puissent comprendre”. Cyt. za: P. Malaurie, Anthologie de la pensée juridique, Paris 1996, s. 287.

${ }^{7}$ J. Bentham, Wprowadzenie do zasad moralności i prawodawstwa, Warszawa 1958.

${ }^{8}$ C. Beccaria, O przestępstwach i karach, Łódź 2014.

${ }^{9}$ P. Beaumarchais, Wesele Figara, Kraków 2003.

${ }^{10}$ G. Cornu, Linguistique juridique, Paris 2005, s. 19. 
będzie przez niego zdominowany ${ }^{11}$. W innej dziewiętnastowiecznej perspektywie, zwiastującej nadejście ,jednojęzyczności państwowej”, dominuje idea, że prawo musi być związane z językiem narodowym. Na uwagę zasługuje również koncepcja szkoły historycznej prawa, według której prawo i język kroczą i rozwijają się w sposób niejako organiczny i podporządkowane są tej samej ewolucji. „Prawo i język żyją w świadomości narodu" - pisał Savigny ${ }^{12}$. Nawiązał w ten sposób do bronionej przez Hugo ${ }^{13}$ tezy o istnieniu "genetycznego" związku między prawem pozytywnym a językiem narodu. Sam Hugo utrzymywał, że prawo pozytywne czerpie swą substancję nie tyle z racjonalnych kalkulacji, co z języka, zwyczajów i tradycji. Z romantycznym zapałem głosił też swoje poglądy Grimm ${ }^{14}$, wskazując na bliskie pokrewieństwo języka i prawa, które będąc „zakorzenionymi” w świadomości narodu, rozwijają się w jej rytmie. Te zbieżne tezy, którym talent autorów przydaje zarówno kolorów, jak i żywotności, wydają się być godne uwagi, ponieważ ukazują zainteresowanie, jakim cieszyły się relacje między językiem a prawem w XIX wieku.

Tymczasem twierdzeniu, że prawo musi być związane z językiem zaprzecza doktryna kanadyjska, gdzie common low i kodeks prawa cywilnego występują w językach francuskim i angielskim. Przykład stosunków międzynarodowych, gdzie system prawa ponadpaństwowego istnieje w wielu językach, także ukazuje ułomność tej koncepcji. Jednak bezsporną zasługą historycznej szkoły prawa pozostaje teza o wspólnym rodowodzie języka i prawa.

Założenie o istnieniu głębokich relacji między językiem a prawem pozwala je zdefiniować jako zjawiska społeczne, wykształcone co najmniej zwyczajowo, o wiążącym, normatywnym charakterze ${ }^{15}$. To właśnie ze zwyczaju język i prawo, chociaż w różnym stopniu, czerpią swoją siłę i pochodzenie ${ }^{16}$. Są to więc zjawiska historyczne i zwyczajowe. Jednocześnie, jako ,żywe” struktury, podlegają ciągłej ewolucji, co oznacza, że zachodzą w nich nieustanne zmiany mające na celu maksymalne usprawnienia oraz dostosowanie do zmieniającej się rzeczywistości. Język i prawo podlegają działaniom wpływów zewnętrznych, co znajduje swoje odbicie $\mathrm{z}$ jednej strony we wprowadzaniu neologizmów, a $\mathrm{z}$ drugiej - w innowacjach legislacyjnych. Ostatecznie tym, co przypieczętowuje pokrewieństwo języka i prawa jest kultura. Aspekt ten, chociaż bywa prawie niezauważalny w przypadku ustawodawcy jednojęzycznego, staje się wyrazisty w przypadku ustawodawcy

${ }^{11}$ Temat ten był szeroko omawiany w literaturze germańskiej. Zob. E.P. Haba, Études en allemends sur les rapports entre droit et langue, [w:] Archives de philosophie du droit, Vol. 19: Le langage du droit, Paris 1974, s. 257-289.

${ }^{12}$ S. Goyard-Fabre, Les embarras philosophiques du droit naturel, Paris 2003, s. 292.

${ }^{13}$ Ibidem.

${ }^{14}$ Ibidem.

${ }^{15}$ J. Carbonnier, Droit civil, Paris 2002.

${ }^{16}$ G. Cornu, op. cit., s. 4. 
wielojęzycznego (jak Kanada, Belgia, Szwajcaria, Unia Europejska). Licznych przykładów ilustrujących to zjawisko dostarczają doświadczenia zdobyte przez kraje, w których spotykają się różne kultury prawne i języki.

\section{ZNACZENIE JURYSLINGWISTYKI}

Hybrydowy charakter juryslingwistyki, jak sama nazwa wskazuje, wymaga spojrzenia na przedmiot badań z dwóch różnych perspektyw: prawa i językoznawstwa. $Z$ jednej strony obejmuje ona zagadnienia ciekawe i ważne z punktu widzenia studiów nad językami specjalistycznymi, tj. tłumaczenia tekstów prawa, tłumaczenia sądowe, dydaktykę przekładu tekstów prawa, terminologię prawa, analizę dyskursu, strukturę i semantykę tekstów prawa itp. Z drugiej natomiast juryslingwistyka jest niezwykle istotna dla prawników przy interpretacji przepisów prawa unijnego i krajowego, szczególnie wtedy, gdy pojawiają się błędy w tłumaczeniu. Na przykład prawo własności przemysłowej w art. 296 ust. 2 pkt 3 stanowi:

Naruszenie prawa ochronnego na znak towarowy polega na bezprawny m używaniu w obrocie gospodarczym znaku identycznego lub podobnego do renomowanego znaku towarow e go, zarejestrowanego w odniesieniu do jakichkolwiek towarów, jeżeli takie używanie może przynieść używającemu nienależną korzyść lub być szkodliwe dla odróżniającego charakteru bądź renomy znaku wcześniejszego.

Polski ustawodawca uznał za naruszenie prawa ochronnego bezprawne używanie w obrocie gospodarczym znaku identycznego bądź podobnego do renomowanego znaku towarowego, zarejestrowanego w odniesieniu do jakichkolwiek towarów, jeżeli takie używanie może przynieść używającemu nienależną korzyść lub być szkodliwe dla odróżniającego charakteru bądź renomy znaku wcześniejszego. Jednak przepis ten nie implementuje należycie art. 5 ust. 2 dyrektywy 2008/95/WE, ponieważ nie zawiera przesłanki uzasadnionych powodów ${ }^{17}$. Dokładna lektura porównawcza art. 5 ust. 2 dyrektywy „znakowej” (nr 2008/95) w wersji polskiej, francuskiej i angielskiej pozwala dostrzec istniejące różnice:

1. Art. 5 ust. 2 dyrektywy ,znakowej” (nr 2008/95) w wersji polskiej:

Każde państwo członkowskie może również postanowić, że właściciel jest uprawniony do zakazania wszelkim osobom trzecim, które nie posiadają jego zgody, używania w obrocie handlowym: oznaczenia identycznego lub podobnego do znaku towarowego w odniesieniu do towarów lub usług, które nie są podobne do tych, dla których zarejestrowano znak towarowy, w przypadku gdy cieszy się on renomą we Wspólnocie i w przypadku gdy używanie tego oznaczenia bez

${ }^{17}$ R. Skubisz, Kolizja późniejszego znaku towarowego z wcześniejszym renomowanym znakiem towarowym. Glosa do wyroku ETS z 27 listopada 2008 r. w sprawie C-252/07 Intel, „Europejski Przegląd Sądowy" 2009, z. 2, s. 37-38. 
uzasadnionego pow odu stanowi nieuprawnione wykorzystanie jego odróżniającego charakteru lub renomy lub jest dla nich szkodliwe.

2. Art. 5 ust. 2 dyrektywy ,znakowej” (nr 2008/95) w wersji francuskiej:

Tout État membre peut également prescrire que le titulaire est habilité à interdire à tout tiers, en l'absence de son consentement, de faire usage dans la vie des affaires d'un signe identique ou comparable à la marque pour des produits ou des services qui ne sont pas comparables à ceux pour lesquels la marque est enregistrée, lorsque celle-ci jouit d'une renommée dans l'État membre et que l'usage du signe sans juste motif tire indûment profit du caractère distinctif ou de la renommée de la marque ou leur porte préjudice.

\section{Art. 5 ust. 2 dyrektywy „,znakowej” (nr 2008/95) w wersji angielskiej:}

Any Member State may also provide that the proprietor shall be entitled to prevent all third parties not having his consent from using in the course of trade any sign which is identical with, or similar to, the trade mark in relation to goods or services which are not similar to those for which the trade mark is registered, where the latter has a reputation in the Member State and where use of that sign without due cause takes unfair advantage of, or is detrimental to, the distinctive character or the repute of the trade mark.

Można zauważyć, że w art. 296 ust. 2 pkt 3 Prawa własności przemysłowej nie występują wyrażenia: „które nie posiadają jego zgody” („,en l'absence de son consentement”, „not having his consent”) ani „bez uzasadnionego powodu” (,sans juste motif”, „without due cause”). Natomiast przetłumaczenie „dans l'État membre”, „in the Member State” na „we Wspólnocie” (art. 5 dyrektywy nr 2008/95) jest jaskrawym przykładem niedbalstwa, gdyż oczywiście chodzi tutaj o państwo członkowskie, a nie o wspólnotę.

Z tego wynika, że znajomość języków specjalistycznych jest ważnym narzędziem pracy nie tylko tłumacza, ale i prawnika, który potrafi wychwycić ewentualne błędy w thumaczeniu tekstów prawa i ograniczyć ich konsekwencje.

Język prawa różni się od innych języków specjalistycznych m.in. tym, że dotyczy konkretnej rzeczywistości prawnej, politycznej i społecznej, dlatego traktowany jest w teorii przekładu prawniczego jako narzędzie komunikacji międzykulturowej. Interpretacja tekstów prawnych, w odróżnieniu od innych tekstów, wymaga znajomości reguł wykładni prawa w celu ustalenia rzeczywistej woli ustawodawcy. Często zwroty użyte w tekście prawa mają swoiste znaczenie, zupełnie inne od znaczenia nadanego im w języku ogólnym. Ustawodawca, ustalając własne zasady interpretacji, tworzy nowe terminy i nadaje im oficjalne znaczenie. Jednocześnie tłumacz tekstów prawnych musi posiadać wiedzę specjalistyczną, aby móc uwzględnić pozatekstowe aspekty znaczenia wyrazów, np. „renomowany znak towarowy” lub „znak wcześniejszy”. 
Zróżnicowanie wiedzy na specjalistyczną i ogólną stanowi podstawę podziału uczestników komunikacji na ekspertów i laików w danej dziedzinie wiedzy. Teksty prawne różnią się od innych tekstów specjalistycznych przede wszystkim funkcją normatywną, wyrażając nakazy, zakazy i dozwolenia oraz tworząc prawa i obowiązki sankcjonowane przez prawo. W konsekwencji tłumacze specjalizujący się $\mathrm{w}$ thumaczeniach tekstów prawa pracują na dwóch poziomach: najpierw interpretują poprawnie sens komunikatu zredagowanego w języku „A”, potem odtwarzają go w języku „B” według zasad sztuki tłumaczenia specjalistycznego.

\section{PODSUMOWANIE}

W Kanadzie wyróżnia się cztery grupy prawników, którzy stosują prawo kanadyjskie: francuskojęzyczni prawnicy działający w ramach kultury prawa stanowionego, anglojęzyczni prawnicy działający w ramach kultury common law, francuskojęzyczni prawnicy działający w ramach kultury common law oraz anglojęzyczni prawnicy działający w ramach kultury prawa stanowionego. Muszą oni znajdować w obu wersjach językowych aktu prawnego taką terminologię i sformułowania, które uwzględniają i odzwierciedlają pojęcia i instytucje charakterystyczne dla kultury prawnej jego prowincji lub terytorium, dlatego też juryslingwistyka rozwija się w Kanadzie w sposób bardzo dynamiczny.

Na podobnych zasadach odbywa się tworzenie wielojęzycznego prawa na terytorium Unii Europejskiej, gdzie jest ono (np. rozporządzenia UE) formułowane w 24 językach oficjalnych. Natomiast prawo krajowe państwa członkowskiego, wyrażone w jednym (lub kilku) z tych języków, jest stosowane na jego terytorium. Na poziomie terminologicznym oznacza to szukanie właściwego terminu (słowa, wyrażenia) na oznaczenie nowego, autonomicznego pojęcia prawa unijnego. W praktyce taki termin zostaje wyrażony w 24 językach oficjalnych Unii Europejskiej, które są również narodowymi językami państw członkowskich.

Sytuacja, w której dany termin prawny jest wyrażony w więcej niż jednym języku jest charakterystyczna nie tylko dla Unii Europejskiej, ale występuje również w przypadku terminologii prawa międzynarodowego lub prawa państw wielojęzycznych. Jest możliwe także, że terminy oznaczające pojęcia prawne należące do różnych systemów prawnych wyrażane są w tym samym języku (np. język francuski jest stosowany w celu oznaczenia pojęć prawnych należących do systemów prawa m.in. Francji, Belgii i Kanady).

Skutki wzajemnego oddziaływania na siebie różnych języków i kultur prawnych, a także wpływu języka prawa Unii Europejskiej na krajowe języki prawa, są przedmiotem niezwykle interesujących badań w zakresie juryslingwistyki. 


\section{BIBLIOGRAFIA}

Beaumarchais P., Wesele Figara, Kraków 2003.

Beccaria C., O przestępstwach i karach, przeł. E.S. Rappaport, Łódź 2014.

Bentham J., Wprowadzenie do zasad moralności i prawodawstwa, przeł. B. Nawroczyński, Warszawa 1958.

Bourcier D., Le discours juridique : analyses et méthodes, Vol. 53, Paris 1979.

Carbonnier J., Droit civil, Paris 2002.

Cornu G., Linguistique juridique, Paris 2005.

Gémar J.-C., De la traduction (juridique) à la jurilinguistique. Fonctions proactives du traductologue, „Meta” 2005, Vol. 50, nº 4 .

Gémar J.-C., Langage du droit et traduction. Essai de jurilinguistique. The Language of the Law and Translation. Essays on Jurilinguistics, Québec - Montréal 1982.

Gémar J.-C., Traduire ou l'art d'interpréter. Langue, droit et société : éléments de jurilinguistique, 2 Vol., Québec 1995.

Gémar J.-C., Kasirer N., Jurilinguistique : entre langues et droits, Montréal 2005.

Goyard-Fabre S., Les embarras philosophiques du droit naturel, Paris 2003.

Haba E.P., Études en allemends sur les rapports entre droit et langue, [w:] Archives de philosophie du droit, Vol. 19: Le langage du droit, Paris 1974.

Kasirer N., Dire ou définir le droit, „La Revue Juridique Thémis” 1994, Vol. 28 , n¹.

Lerat P., Les langues spécialisées, Paris 1995.

Malaurie P., Anthologie de la pensée juridique, Paris 1996.

Montesquieu Ch.L., Euvres Complètes, Paris 1964.

Perelman Ch., Olbrechts-Tyteca L., La nouvelle rhétorique. Traité de l'Argumentation, Paris 1958.

Skubisz R., Kolizja późniejszego znaku towarowego z wcześniejszym renomowanym znakiem towarowym. Glosa do wyroku ETS z 27 listopada 2008 r. w sprawie C-252/07 Intel, „Europejski Przegląd Sądowy" 2009, z. 2.

Sourioux J.-L., Lerat P., Le langage du droit, Paris 1975.

Wróblewski B., Język prawny i prawniczy, Kraków 1948.

\section{SUMMARY}

The objective of this paper is to provide some lines of general reflection on the special relationship uniting language and law. This approach allows the introduction of a new hybrid discipline, jurilinguistics, that draws upon both the former and the latter. Since jurilinguistics has begun to play a remarkable role in the global legal and economic context (as is the case of the EU), we will try both to show its genesis and its various manifestations, doing so from the perspective of the translation of legal discourse.

Keywords: language; law; legal language; jurilinguistics 